\title{
WSPÓŁCZESNE TEORIE GRZECZNOŚCI JĘZYKOWEJ I ICH WPLYW NA BADANIA W OBSZARZE GLOTTODYDAKTYKI POLONISTYCZNEJ ${ }^{1}$
}

\begin{abstract}
Słowa kluczowe: grzeczność językowa, glottodydaktyka polonistyczna, badania nad grzecznością językową

Streszczenie. Głównym celem artykułu jest przedstawienie ewolucji teorii grzeczności językowej na przestrzeni ostatnich pięćdziesięciu lat. W pierwszej części zestawiono ze sobą najważniejsze założenia trzech klasycznych teorii grzeczności językowej. W kolejnym kroku dokładnie opisano krytykę tych pierwszych podejść oraz zaprezentowano teorie, które powstały na gruncie tej dyskusji. Nazwano je postmodernistycznymi i dyskursywnymi. Cześć trzecia koncentruje się na przywołaniu nazwisk badaczy, którzy wychodzą poza paradygmat postmodernistyczny i dyskursywny. W czwartej części przywołano najnowsze podejścia do badań nad grzecznością językową i przedstawiono, jaki wpływ mają one na badania w obszarze glottodydaktyki polonistycznej.
\end{abstract}

\section{WPROWADZENIE}

W ostatnich 30 latach opublikowano wiele prac badawczych koncentrujących się wokół zagadnienia grzeczności językowej². Okazało się, że grzeczność jest interdyscyplinarną przestrzenią badawczą - czerpie z nauk takich jak socjologia, psychologia czy antropologia kulturowa. Sytuowana jest w obrębie językoznawstwa jako subdyscyplina pragmatyki, nauki badającej znaczenie w interakcji, czy, mówiąc dokładniej, socjopragmatyki.

*emilia.sztabnicka-gradowska@p.lodz.pl, Politechnika Lódzka, Centrum Językowe, al. Politechniki 12, 90-924 Łódź.

${ }^{1}$ Niniejszy artykuł powstał na podstawie obserwacji poczynionych w związku z przygotowywaniem rozprawy doktorskiej pt. Model polskiej grzeczności językowej w nauczaniu języka polskiego jako obcego. Perspektywa interkulturowa, napisanej pod kierunkiem prof. nadzw. UŁ dr hab. Grażyny Zarzyckiej w Zakładzie Lingwistyki Stosowanej i Kulturowej UŁ.

${ }^{2}$ Richard Watts (2003, s. XI) napisał, że bibliografia prac językoznawczych, których tematem jest grzeczność językowa, opiewa na ponad 1200 tytułów i z tygodnia na tydzień liczba ta rośnie. 
Na rozwój badań nad grzecznością językową wpływ miały przede wszystkim dwa czynniki. Pierwszym było pojawienie się konceptu „twarzy”, znane najlepiej w ujęciu Ervinga Goffmana (1967). „Twarz” to społeczny wizerunek, który każda osoba posiada i którym zarządza w procesie interakcji. Kolejnym czynnikiem było zaciekawienie nowymi, na owe czasy, ideami filozofów języka. Szczególnie interesujące dla pragmalingwistów okazały się: teoria aktów mowy Austina $(1962,1993)$ i Searla $(1969,1987)$ oraz maksymy konwersacyjne Grice'a (1977). Wszystkie te elementy przyczyniły się do zapoczątkowania naukowej dyskusji nad fenomenem grzeczności językowej. Terminologię związaną z tym pojęciem zawdzięczamy głównie Robin Lakoff (1973), która w latach siedemdziesiątych ubiegłego wieku wprowadziła badania nad grzecznością do lingwistyki. W następnej dekadzie powstała zaś powszechnie znana teoria grzeczności autorstwa Penelope Brown i Roberta Levinsona (1987) oraz nieco mniej popularna koncepcja, której autorem był Geoffrey Leech (1983).

Zaciekawienie paradygmatem grzeczności zaproponowanym przez Brown i Levinsona trwa do dziś, choć oddziaływanie tej teorii znacznie się zmniejszyło. 2001 rok okazał się bowiem przełomowy. Wtedy właśnie ukazała się książka Gino Eelena Critique of Politeness Theories (2001), w której autor wykazał fałszywość bądź „naiwność” kluczowych założeń teorii nazywanych dziś klasycznymi ${ }^{3}$. Inni wpływowi badacze, tacy jak Sara Mills (2003) czy Richard Watts (2003), również zauważyli braki w koncepcjach wcześniejszych, a ich rozważania przyczyniły się do rozwoju innego paradygmatu w badaniach nad grzecznością językową. Ten nowy nurt nazywany jest postmodernistycznym i dyskursywnym, jego główne założenia powstały na bazie głosów krytycznych wobec klasycznych teorii. Część badaczy zupełnie odcina się więc od koncepcji Brown i Levinsona, inni zaś próbują zredefiniować dorobek poprzedników.

Równolegle do wyżej opisywanych przemian dokonywało się także rozszerzenie geograficzne zainteresowań nad grzecznością językową. Analizowano np. możliwość zastosowania klasycznych koncepcji do badania języków azjatyckich ${ }^{4}$. $\mathrm{Na}$ atrakcyjności zyskało podejście interkulturowe, które bada, między innymi, różnice w zachowaniach grzecznościowych w obrębie różnych kultur.

W 1998 roku w Wielkiej Brytanii zawiązała się też grupa badawcza, która do dziś funkcjonuje pod nazwą Linguistic Politeness Research Group ${ }^{5}$. Jej podstawowym zadaniem, jak można przeczytać na oficjalnej stronie internetowej, jest wypracowanie nowych metod badawczych i teorii. Grupa regularnie organizuje seminaria i konferencje naukowe, skupiając środowisko badaczy, liczące dziś ponad 150 osób z różnych części świata. Efektem prac tej grupy jest także założenie w 2005 roku czasopisma Journal of Politeness Research:

\footnotetext{
${ }^{3}$ Za klasyczne teorie uważam prace Lakoff, Brown i Levinsona (1987) oraz Leecha (1983).

${ }^{4}$ Ide (1989) język japoński.

${ }^{5}$ http://research.shu.ac.uk/politeness/ [15.05.2019].
} 
Language, Behaviour, Culture. Od tego momentu każdego roku ukazują się dwa tomy czasopisma, w których publikują badacze zajmujący się grzecznością językową.

\section{KLASYCZNE TEORIE GRZECZNOŚCI JĘZYKOWEJ}

Badania nad grzecznością językową zostały zapoczątkowane w latach siedemdziesiątych dwudziestego wieku. Pierwszą koncepcję zaproponowała Robin Lakoff (1973). Zaraz potem rezultaty swoich badań nad etykietą językową przedstawili Penelope Brown i Robert Levinson $(1978,1987)$ oraz Geoffrey N. Leech (1983). Wszystkie te koncepcje spotkały się z jednej strony z entuzjazmem i uznaniem, co spowodowało pojawienie się wielu kolejnych badań empirycznych, bazujących na założeniach powyższych teorii, z drugiej zaś strony badacze ci ściągnęli na siebie lawinę krytyki ${ }^{6}$.

Porównanie tych trzech znanych teorii ująć można w formie tabeli, która prezentuje elementy wspólne, jak choćby podobne ujęcie definicji grzeczności, ale też powiązanie z filozofią Grice'a, czy aspekty, które różnicują je, jak na przykład pojmowanie uniwersalności zasad zachowań grzecznościowych.

Tabela 1. Zestawienie podstawowych elementów klasycznych teorii grzeczności językowej

\begin{tabular}{|c|c|c|c|}
\hline & $\begin{array}{c}\text { Koncepcja Robin Lakoff } \\
\text { (1973) }\end{array}$ & $\begin{array}{l}\text { Teoria Brown i Levinsona } \\
\text { (1987) }\end{array}$ & $\begin{array}{c}\text { Koncepcja } \\
\text { Geoffrey'a Leecha (1983) }\end{array}$ \\
\hline $\begin{array}{l}\text { Stosunek do maksym } \\
\text { konwersacyjnych } \\
\text { Grice'a }\end{array}$ & $\begin{array}{l}\text { Zasady grzecznościowe } \\
\text { nie stoją w sprzeczności } \\
\text { z maksymami } \\
\text { konwersacyjnymi. }\end{array}$ & $\begin{array}{l}\text { Zasady grzecznościowe } \\
\text { są w opozycji do maksym } \\
\text { konwersacyjnych. }\end{array}$ & $\begin{array}{l}\text { Zasady grzecznościowe } \\
\text { nie stoją w sprzeczności } \\
\text { z maksymami } \\
\text { konwersacyjnymi. }\end{array}$ \\
\hline $\begin{array}{l}\text { Pojmowanie } \\
\text { grzeczności }\end{array}$ & \multicolumn{3}{|c|}{$\begin{array}{l}\text { Grzeczność jest racjonalna, oparta na regułach, które zarządzają zachowaniem, } \\
\text { zakorzeniona w potrzebie człowieka do prowadzenia harmonijnych stosunków } \\
\text { międzyludzkich i unikania konfliktów. }\end{array}$} \\
\hline $\begin{array}{l}\text { Rozumienie } \\
\text { uniwersalności zasad } \\
\text { grzecznościowych }\end{array}$ & $\begin{array}{l}\text { Różna pozycja } \\
\text { poszczególnych zasad } \\
\text { w hierarchii w danej } \\
\text { kulturze. }\end{array}$ & $\begin{array}{l}\text { Silne przekonanie } \\
\text { o uniwersalnej naturze } \\
\text { zasad grzecznościowych. }\end{array}$ & $\begin{array}{l}\text { Jedynie specyficzne } \\
\text { warunki kulturowe } \\
\text { mogą mieć mały wpływ } \\
\text { na odstępstwa od } \\
\text { uniwersalności. }\end{array}$ \\
\hline \multirow{3}{*}{$\begin{array}{l}\text { Podobieństwa } \\
\text { terminologiczne }\end{array}$} & $\begin{array}{l}\text { Reguła dawania wyboru } \\
\text { interlokutorowi. }\end{array}$ & & $\begin{array}{l}\text { Reguła dawania wyboru } \\
\text { interlokutorowi, skala } \\
\text { wyboru. }\end{array}$ \\
\hline & & $\begin{array}{l}\text { Dystans społeczny, } \\
\text { autorytet. }\end{array}$ & $\begin{array}{l}\text { Dystans społeczny, } \\
\text { autorytet. }\end{array}$ \\
\hline & & $\begin{array}{l}\text { Grzeczność jest } \\
\text { przeciwieństwem } \\
\text { bezpośredniości. }\end{array}$ & $\begin{array}{l}\text { Grzeczność jest } \\
\text { przeciwieństwem } \\
\text { bezpośredniości. }\end{array}$ \\
\hline
\end{tabular}

Źródło: opracowanie własne na podst.: Sifianou 2010, s. 23-24 i Eelen 2001, s. 20-23

${ }^{6}$ Watts, Ide and Ehlich 1992, Eelen 2001. 
Istotnym aspektem jest tu też umiejscowienie badań nad grzecznością językową w obszarze lingwistyki. Teorie powyższe czerpią inspirację zarówno z pragmatyki; porównaj następujące zagadnienia i koncepty:

- reguły i zasady rządzące systemem,

- akty mowy jako elementy systemu językowego,

- przekonanie o twórczej roli języka,

- bezpośredniość jako intencjonalne działanie,

- możliwość wyrażania tej samej intencji w różny sposób,

- jak i z socjolingwistyki; porównaj poniższe koncepty:

- uniwersalizm fenomenu grzeczności w różnych kulturach i językach świata,

- typy różnic w realizacji poszczególnych zachowań grzecznościowych w językach,

- różne formy i funkcje grzeczności w zależności od kontekstu

Lakoff, Ide 2005, s. 9-10.

\section{ZWROT POSTMODERNISTYCZNY}

Najobszerniejszym i zapewne także najbardziej znanym i rozpowszechnionym modelem grzeczności była koncepcja stworzona przez Penelope Brown i Stephena Levinsona. Wydana w 1987 roku publikacja, zawierająca pełen opis teorii, spotkała się z dużym zainteresowaniem. Wielu badaczy opierało na tym modelu swoje analizy. Derek Bousfield (2008, s. 2) podaje, że od momentu publikacji artykułu Robin Lakoff w 1973 roku powstało ponad tysiąc książek i artykułów naukowych o fenomenie grzeczności. Były to publikacje zarówno teoretyczne, jak i empiryczne. Niebawem jednak pojawiły się także głosy krytyki wobec klasycznych ujęć zjawiska grzeczności. Zmianę perspektywy w badaniach nad grzecznością językową zapoczątkował Gino Eelen, który w wydanej w 2001 roku monografii, wskazał na miejsca problematyczne w klasycznych koncepcjach grzeczności i jednocześnie wyznaczył kierunek zmian. Eelen (za: Mills 2011, s. 20) sformułował kilka zarzutów wobec teorii klasycznych, a mianowicie:

- zbyt duże oparcie się autorów koncepcji na teorii aktów mowy,

- zbyt naiwną koncepcję modelowego człowieka,

- uproszczony model komunikacji,

- fałszywe definiowanie grzeczności,

- błędne założenie o uniwersalności zachowań grzecznościowych. 
W następnych latach także Richard Watts (2003) oraz Sara Mills (2003) skrytykowali podejście Brown i Levinsona. We wszystkich tych głosach dezaprobaty przewija się stwierdzenie o nieracjonalności badania zjawiska grzeczności językowej w oderwaniu od kontekstu, sprowadzenie komunikacji do prostych i bezwyjątkowych reguł oraz zbyt duże akcentowanie intencji nadawcy w wymianie, a co za tym idzie, przyjęcie fałszywego obrazu interakcji.

\subsection{KRYTYKA KLASYCZNYCH TEORII GRZECZNOŚCI JĘZYKOWEJ}

Brown i Levinson oparli swój model grzeczności na teorii aktów mowy mimo tego, iż natrafili na pewne problemy w jej aplikacji. Żadna inna koncepcja nie mogła jednak najprawdopodobniej zastąpić w tym czasie teorii aktów mowy. Najczęściej przedmiotem analizy badaczy zajmujących się grzecznością językową były akty przeprosin i prośby. Badania ilościowe skupiały się np. na zliczaniu realizacji próśb w materiale językowym. Wyróżnianie aktów mowy jako jednostek analizy uniemożliwiało jednak często uchwycenie zjawiska grzeczności w pełni. Włączano bowiem do badania jedynie te elementy, które zawierały wprost wyrażoną prośbę, pomijając te, które tę samą funkcję spełniały z użyciem innych środków językowych. System ten działał także w drugą stronę - nie brano pod uwagę tego, że czasem użycie zwrotu ,przepraszam” wcale nie miało służyć funkcji przepraszania. Innymi słowy, tylko nadawca i odbiorca komunikatu mogą szyfrować i deszyfrować przekaz. To ich intencja jest kluczowym elementem, na którym powinien opierać się podział środków językowych wyrażających funkcje grzecznościowe.

Teoria Brown i Levinsona zakłada również, że w akcie komunikacji bierze udział „modelowy człowiek”. Każdy uczestnik rozmowy działa racjonalnie, by osiągnąć zamierzone cele. Kalkuluje i wybiera najlepszą, najbardziej skuteczną drogę, żeby jego intencja została spełniona. Taki model człowieka jest charakterystyczny dla filozofii Zachodu. Idea ta niesie jednak za sobą pewne konsekwencje. Wyklucza bowiem działanie innych jednostek oraz społeczeństwa. Sprawia, że otoczenie społeczne jest wykorzystywane jedynie jako środek do osiągnięcia celu przez modelowego człowieka. Eelen (2001, s. 35) zaznacza, że ta indywidualistyczna koncepcja natury ludzkiej nawet w społeczeństwach zachodnich jest jednak ograniczona do pewnych sfer życia, natomiast w krajach arabskojęzycznych, czy w Azji, zupełnie nie ma racji bytu.

Ciekawych analogii dokonała Sachiko Ide (Lakoff, Ide 2005, s. 47-48), charakteryzując różnice występujące między Wschodem i Zachodem. Przywołała sformułowanie geologa Hideo Suzukiego, określające prototyp człowieka Wschodu jako „myślącego w lesie”. W opozycji do tego utworzyła prototyp czło- 
wieka Zachodu jako „orła szybującego po niebie”. Te dwa określenia przedstawiają różnice w sposobie postrzegania świata. „Myślący w lesie” zawsze bierze pod uwagę otaczające go jednostki, nie działa indywidualistycznie, zanurzony jest w społeczności, która oddziałuje na niego tak samo, jak on na pozostałe elementy tej struktury. „Orzeł szybujący po niebie” to wyrazista metafora jednostki działającej indywidualistycznie, bez wpływu otoczenia społecznego, nastawionej na osiągnięcie celów i zaspokojenie potrzeb.

Te idealne modele nie występują w czystej postaci w świecie realnym, są jednak pewnymi punktami odniesienia. Zapewne w kulturze Wschodu, czy precyzyjniej, w modelu grzeczności Wschodu, istnieją pewne elementy tego indywidualistycznego obrazu Zachodu; i na odwrót. Fakt niepodważalny jest jednak taki, że koncepcja grzeczności oparta tylko na założeniach indywidualizmu nie może być teorią ogólną.

Autorzy książki Politeness: Some Universals in Language Uses (Brown, Levinson 1987) uznali też, że proces komunikacji zachodzi bez jakichkolwiek zaburzeń. Nadawca i odbiorca komunikatu współpracują i uzyskują zamierzony efekt. Tymczasem w realnym świecie taki idealny przebieg procesu komunikacji zdarza się rzadko. Badacze języka i kultury (Mills 2003; Watts 2003) wskazują, że szczególnie gdy chodzi o grzeczność, taka modelowa sytuacja wydaje się niemożliwa. Wynika to z faktu, że relacje międzyludzkie i status jednostki są wciąż negocjowane. Dlatego też model komunikacji, zaproponowany przez Brown i Levinsona w ich teorii grzeczności, spotkał się z dużą krytyką i jest poważnym obciążeniem dla weryfikowalności tej koncepcji.

Innym zarzutem wobec definicji Brown i Levinsona jest to, iż nie przedstawiono tam szerszego wyjaśnienia pojęcia niegrzeczności. Definiowanie grzeczności i niegrzeczności nie jest bowiem tak oczywiste, jak wynikałoby to z ich nazw. Badacze (Culpeper 2005; Bousfield 2008) udowodnili, że można analizować niegrzeczność jako zjawisko zupełnie różne od grzeczności, niesprowadzające się jedynie do jej opozycji.

Jeszcze więcej krytyki w teorii Brown i Levinsona wzbudził koncept uniwersalności grzeczności. Autorzy Politeness: Some Universals in Language Uses założyli, że koncepcja zachowania twarzy, obecna w zjawisku grzeczności, jest uniwersalna, mimo że poszczególne grupy językowe mogą wyrażać grzeczność na różne sposoby. Badacze z Azji Wschodniej (Ide 1989; Song 2012) wykazali jednak, że podejście takie nie jest trafne. Grzeczność w różnych kulturach opiera się na innych wartościach i, chociaż można mówić o pewnej uniwersalności, to poszczególne zachowania grzecznościowe mogą mieć i zapewne mają różne funkcje i znaczenia. 


\subsection{NOWE DROGI - PODEJŚCIE POSTMODERNISTYCZNE I DYSKURSYWNE}

Zdaniem części językoznawców (Mills 2003; Watts 2003) zwrot, jaki dokonał się w postmodernizmie, polega na odejściu od badań ilościowych. Ma to szczególne znaczenie w przypadku badań nad grzecznością. Materiał badawczy jest bowiem niejednorodny i trudno sprowadzić go do prostych formuł grzecznościowych, które dałoby się policzyć. Sposób odczytywania tych formuł zależy od odbiorcy i nade wszystko od kontekstu. Niemożliwe jest więc przypisanie im stałego znaczenia czy funkcji. To dana sytuacja nadaje im sens. Analiza powinna więc zawsze być kontekstualna.

Mills (2003) i Watts (2003) podkreślają, że to także pojęcie dyskursu zmieniło podejście do badań nad grzecznością. Zasadniczy zwrot polega tu na rezygnacji z analizy wyizolowanych formuł czy wypowiedzi. Słowa i zdania nie tworzą bowiem grzeczności, jej fenomen powstaje dzięki siłom władzy i zależności. Foucault podkreśla rolę dyskursu w strukturyzacji tego, co postrzegamy jako realne. Ważne jest, by analizować te dyskursywne ograniczenia, które wpływają na jednostkę, bo sam człowiek nie decyduje po prostu o tym, do jakich reguł grzecznościowych się zastosować. To dyskurs narzuca mu postępowanie.

Zakotwiczenie badań nad grzecznością w nurcie postmodernistycznym i dyskursywnym zmieniło optykę spojrzenia na prowadzanie analiz w tym obszarze naukowym. To Eelen (2001) swoją ostrą krytyką teorii Brown i Levinsona zachęcił badaczy do poszukiwania nowych rozwiązań. Wskazał na istotność rozróżnienia między grzecznościa 1 rozumianą jako to, co oznacza grzeczność dla uczestników interakcji i grzecznościa 2 - pojmowaniem grzeczności przez badaczy i rozumianą jako akademickie generalizacje dotyczące jej fenomenu. Dyskursywne teorie grzeczności są odpowiedzią na krytykę modelu Brown i Levinsona. Niektóre z nich rozwijają lub uzupełniają tę propozycję, inne zaś zbudowały swą tożsamość w opozycji do niej.

Badacze grzeczności językowej zaczęli poszukiwać inspiracji i podstaw do prowadzenia badań $\mathrm{w}$ różnych koncepcjach z dziedziny nauk społecznych. Jedną z nich jest propozycja Pierre'a Bourdieu (1991, s. 12), który powołał do życia pojęcie habitusu. Zdefiniował je jako zbiór zachowań, które przyswajamy $\mathrm{w}$ procesie socjalizacji. Funkcjonowanie w danej społeczności uruchamia procesy, które są odpowiedzialne za uczenie się tych wzorów. Najczęściej jest to po prostu ich powtarzanie bez refleksji nad ich sensem ${ }^{7}$. Terkourafi (2005a, s. 253)

${ }^{7}$ Porównaj hasło habitus ze Słownika socjologii jakościowej pod red. K. T. Koneckiego, P. Chomczyńskiego (Byczkowska 2012, s. 102-103): „Habitus jest zatem przystosowaniem się do warunków, w jakich funkcjonuje grupa. (...) Ważne jest wpojenie schematów myślowych, sposobów postrzegania rzeczywistości, dyspozycji psychicznych tak, aby osoby, które są członkami grupy, powielały korzystny dla niej schemat - nie jest konieczne, by robiły to świadomie. Ważniejsza jest tu forma niż treść, ale forma, która wynika z rzeczywistości, w której została ukształtowana". 
zauważyła, że w podobny sposób funkcjonują w społeczności wzory zachowań grzecznościowych. Dzieci nabywają je w procesie socjalizacji i te normy potem warunkują nasze wybory językowe. Najczęściej jesteśmy nieświadomi faktu, że nasze zachowanie „regulowane” jest przez system reguł. Ich obecność staje się jednak oczywista w momencie spotkań z przedstawicielami innych kultur. Różnice w wyborze strategii językowych mających spełnić daną funkcję sprawiają, że proste przetłumaczenie zdania z jednego języka na drugi może okazać się błędne, może przynieść inny efekt illokucyjny czy wprowadzić w zakłopotanie.

Sara Mills (2003) połączyła w swoich badaniach koncepcję habitusu z ideą Community of Practice. Koncepcja ta stworzona została przez Etienne Wengera (1998). Jego celem było uchwycenie praktyk językowych, które można zaobserwować, gdy dana grupa ludzi pracuje wspólnie nad jakimś zadaniem. Interakcje, jakie zachodzą między uczestnikami, są spoiwem grupy, ale też elementem budującym jej indywidualny styl językowy. Badania oparte na tej koncepcji znalazły zastosowanie w obszarze analiz języka różnych płci. Mogą być także wykorzystywane przy rozpatrywaniu pojęcia grzeczności. To grupa tworzy normy grzecznościowe, ona decyduje, na zasadzie negocjacji, co uznać za grzeczne, a co za niegrzeczne. Praktycznym zastosowaniem tego konceptu do badań nad grzecznością językową jest praca Sary Mills (2003). Badaczka ta skoncentrowała się na wpływie płci na zachowania grzecznościowe. Naczelnym elementem pracy Mills jest oparcie się na pojęciu dyskursu. Za Foucault (1977) przyjęła, że dyskurs jest „nieskończonym zbiorem elementów wciąż powracających z dyskursów wcześniejszych. Sprawia wrażenie spójności, ale zawsze jest rezultatem jakiegoś połączenia, istniejących kiedyś części" (za: Watts 2010, s. 56). Mills uważa, że zjawisko grzeczności zależy od historycznego rozwoju społeczności, które dzielą wspólne przekonania i sposoby zachowania. Te grupy ludzi nazywa, za Wengerem, Communities of Practice.

Inną teorią, zaczerpniętą tym razem z lingwistyki, a wykorzystywaną na gruncie badań nad grzecznością, jest teoria relewancji. Badania oparte na tym paradygmacie prowadził Watts (2003). Model interakcji zaoferowany przez tę koncepcję, jest bardziej zróżnicowany i szczegółowy niż ten oparty na teorii aktów mowy czy maksymach Grice'a. Badacze sądzą, że teoria relewancji pozwala na określenie, czy dana formuła jest postrzegana przez odbiorcę jako grzeczna bądź niegrzeczna.

Jeszcze inny paradygmat badawczy oferuje frame-based analysis. To podejście do badań nad grzecznością wykorzystuje Terkourafi (2005a, 2005b). Ramą jest tu zestaw oczekiwań, który wynika z doświadczenia. Jeśli w przeszłości ktoś zwracał się do nas w danym kontekście w pewien sposób, będzie to stanowić wzór, model, na podstawie którego będziemy budować wypowiedzi w podobnych sytuacjach. Ma to ścisły związek z pojęciem habitusu. Takie podejście pozwala na uzyskanie danych ilościowych. Na podstawie używanych formuł językowych 
wnioskuje się, jakie normy obowiązują w danym kontekście. Terkourafi (2005a, s. 247) uważa, że można określić normy grzecznościowe funkcjonujące w danej społeczności i przewidzieć, jakie formuły językowe będą stosowane przez użytkowników w danej sytuacji. W zasadzie jest to podejście podobne do tego wypracowanego przez Brown i Levinsona (1987), odwrócono jednak perspektywę - to użytkownicy języka orzekają, jakie formuły językowe realizują daną funkcję. Co do wprowadzania nowych rozwiązań w sytuacjach, kiedy użytkownik nie ma do dyspozycji ramy, punktu odniesienia Terkourafi (2005a, s. 248) zakłada, że istnieje możliwość innowacji. Wskazuje jednak, że może wtedy dojść do niezrozumienia intencji.

Naomi Geyer (2008) w badaniach nad grzecznością zastosowała dyskursywną psychologię, analizę konwersacyjną i etnometodologię. Arundale (2010, s. 2096) podkreślił, że podejście badawcze oparte na analizie konwersacji pozwala na przedstawienie grzeczności jako osiągnięcia interakcyjnego, a nie produktu samego w sobie, danego jako stały. Analiza taka skupia się na uczestnikach interakcji dążących do osiągnięcia jakiegoś celu. W tym podejściu specjalne miejsce zajmuje też pojęcie kultury. Jest ona bowiem traktowana jako część wiedzy ogólnej, którą posiada jednostka, nie jest jednak elementem stałym, niezmiennym, a wręcz przeciwnie - jest wciąż konstruowana w procesie interakcji (za: Mills 2011, s. 34).

Geyer rozwinęła i zredefiniowała także pojęcie twarzy, zaczerpnięte z koncepcji Brown i Levinsona. Przyjęła, że jest to pozytywny obraz siebie, który jest tworzony w dyskursie. Swoje podejście do badań nad grzecznością scharakteryzowała jako „skrzyżowanie języka, kultury, akcji i poznania” (Geyer 2008, s. 57).

\subsection{UJECIE PODOBIEŃSTW W POSTMODERNISTYCZNYCH PODEJŚCIACH DO BADAŃ NAD GRZECZNOŚCIĄ}

Nie wszyscy opisani wyżej badacze określiliby swoje analizy jako zgodne z nurtem postmodernistycznym. Jest to jednak propozycja Sary Mills (2011), która wykazuje, że powyższe przykłady mają cechy wspólne, a co więcej, te właśnie cechy są elementami składowymi podejścia postmodernistycznego. Zasadniczym aspektem jest tu przekonanie o tym, że budowanie teorii uniwersalnych, które mogą ująć różnorodność języków i kultur, jest niemożliwe. Model podobny do tego zaproponowanego przez Brown i Levinsona nie powstanie więc, gdyż musiałby on opierać się na zbyt daleko idących generalizacjach. Badacze postmodernistyczni podążają w stronę analiz w obrębie danego kontekstu oraz przyglądają się baczniej roli uczestników konwersacji. Sposób, w jaki dyskutanci kreują swoje wypowiedzi, mówi o ich miejscu w grupie oraz wartościach, jakie tej grupie 
przypisują. Poza tymi zasadniczymi elementami nurtu postmodernistycznego, istnieje jeszcze więcej aspektów, które wskazują na obecność tego podejścia w najnowszych badaniach nad grzecznością. Należą do nich:

- nowe definicje grzeczności,

- sytuowanie jednostki wobec społeczności,

- wybór metod analizy.

Badacze postmodernistyczni postrzegają grzeczność z innej perspektywy niż lingwiści skupieni wokół koncepcji klasycznej - nie jest ona już środkiem do osiągnięcia celu komunikacyjnego czy strategicznym wyborem w celu uniknięcia konfliktu (Brown i Levinson 1987), ale wynikową działania sił społecznych, kontekstu i statusu jednostki (Mills 2011, s. 36). Ta zmiana perspektywy została zapoczątkowana przez badaczy grzeczności w obrębie języków azjatyckich, takich jak japoński czy chiński, gdzie etykieta wymaga zastosowania danych formuł językowych po to, by zinterpretować swoją pozycję w grupie społecznej i określić relacje między uczestnikami wymiany konwersacyjnej.

W ramach badań postmodernistycznych podejmuje się też próby ujęcia zjawiska grzeczności i niegrzeczności w obrębie jakiegoś szerszego terminu. Jedną z propozycji przedstawiła Miriam Locher (2006, s. 3). Powołała ona do życia pojęcie relational work (praca wspólna, wspólny wysiłek), które oznacza wysiłek/ pracę, jaką jednostki podejmują, by negocjować swoje stosunki z innymi. Idąc dalej tym tropem, Locher (2006) zauważyła, że definicja grzeczności nie może być tożsama dla nadawcy i odbiorcy komunikatu. Grzeczność dla nadawcy jest formą zaakcentowania poprawnego zachowania, ale może on też chcieć wskazać na jakieś swoje obawy, a w tym samym czasie jest motywowany przez egocentryczne popędy. Uczestnik interakcji odbierze wypowiedź jako grzeczną, jeśli będzie ona tak oznaczona i będzie poprawna. Locher i Watts (2005, s. 15) powiększyli także wachlarz określeń, jakimi opatrywana była dotąd grzeczność. Wyróżnili zachowania językowe, które mogą być określone jako neutralne i nienacechowane (appropriate without being marked). Jeszcze innym ważnym punktem rozważań Locher, dotyczącym pojęcia grzeczności, jest wskazanie na zmienność zjawiska. Grzeczność jest oparta na zrozumieniu i ocenie norm, a te są negocjowane i renegocjowane w zależności od kontekstu.

W odmienny sposób definiuje grzeczność Terkourafi (2005a, s. 248). Opierając swoje założenia na koncepcji frame-based analysis, twierdzi, że poszczególne wyrażenia są uważane za grzeczne, gdyż pojawiają się regularnie w danych sytuacjach. Zaznacza jednak, że fenomen grzeczności nie polega na samym zastosowaniu środków językowych, ale na regularności ich pojawiania się. To właśnie zwyczaj, a nie, jak chcieli Brown i Levinson, chłodna kalkulacja, jest kluczowym elementem grzeczności.

Locher i Watts (2005, s. 78) twierdzą, że żadne zachowanie językowe nie jest po prostu grzeczne bądź niegrzeczne, to kontekst pozwala na kategoryzację. 
Leech (za: Mills 2011, s. 38) z kolei w roli sędziów ustanawia uczestników konwersacji; to oni decydują o sile grzeczności wypowiedzi. Jeszcze dalej posunął się Derek Bousfield (2008, s. 187). Wyróżnił on role, jakie jednostki przyjmują w dyskursie; wybrane przez jego uczestników wiążą się z podejmowaniem określonych zachowań, wyborów językowych i konwencji grzecznościowych.

Badacze postmodernistyczni odeszli też od zgodnego z propozycją Brown i Levinsona rozumienia pojęcia twarzy. Odrzucają przekonanie o przyjmowaniu „twarzy”, a zakładają, że jest ona negocjowana, tworzona za każdym razem od nowa w danym kontekście. Terkourafi $(2008$, s. 47) dodaje, że język zachowań grzecznościowych buduje nasz wizerunek, naszą ,twarz”. Geyer (2008, s. 51) zaś przekonuje, że pojęcie twarzy należy uzupełnić o określenie „twarz interakcyjna”, bo to lepiej oddaje jej charakter jako tworu budowanego w procesie interakcji.

Jeszcze innym elementem pojawiającym się w definicjach grzeczności jest pojęcie niegrzeczności (impoliteness). W przypadku badań opartych na paradygmacie postmodernistycznym traktowanie niegrzeczności jako po prostu odwrotności grzeczności przestało być rozwiązaniem wystarczającym. Analizy i badania, które są prowadzone w obrębie grzeczności, nie mogą wykluczać pojęcia niegrzeczności, bo jest ono jednym z wyborów, jaki może się przy tej okazji pojawić.

Najnowsze badania nad grzecznością językową prowadzone są zgodnie z przekonaniem, że to podstawowe pojęcie jest procesem, a nie niezmiennym i danym raz na zawsze tworem. Christie (2007, s. 292) przyjmuje więc, że znaczenie wypowiedzi nie jest jasne i jednoznaczne, dopóki nie zostanie zinterpretowane w danym kontekście. Bousfield (2008, s. 183) traktuje grzeczność jako część interakcji, stąd jego przekonanie, że można śledzić proces, jaki prowadzi do uznania wypowiedzi językowych za grzeczne bądź niegrzeczne. Badacz ten przygląda się jednak także innym elementom interakcji. Bada, jak użycie określonych formuł językowych działa na rozmówców oraz zastanawia się nad wpływem kontekstu na wybór danych środków lingwistycznych.

Po części za sprawą badaczy języków azjatyckich, ale też z powodu zmiany paradygmatu w badaniach nad grzecznością wykształcił się nowy sposób pojmowania jednostki. Nie jest już ona oderwanym od świata zewnętrznego bytem. Jest, można by rzec, jednostką w społeczeństwie, na którą wciąż wpływ ma kontekst społeczny. W procesie interakcji dochodzą do głosu zarówno siły społeczne, kontekst, jak też przekonania jednostki i wtedy dochodzi do uzgadniania i wyboru strategii grzecznościowej.

W nowym paradygmacie także badaczowi przypisuje się inną rolę. Powinien on określać normy poprawnościowe funkcjonujące $\mathrm{w}$ danej społeczności, a następnie wskazywać na formuły grzecznościowe, jakie mogą być uznawane za zgodne z normą. Nie można jednak założyć, że w danym kontekście zostaną one uznane za grzeczne, bo to rozmówcy ostatecznie decydują o ich klasyfikacji normatywnej. 
Samo pojęcie kontekstu oraz jego roli w analizach jest różnie interpretowane. Badacze postmodernistyczni zgadzają się, że badania powinny być oparte na materiale, który nie jest oderwany od kontekstu. Locher (2006, s. 253) wskazuje jednak, że każda analiza będzie wtedy zawężona do tej jedynej, niepowtarzalnej sytuacji. Terkourafi (2005a) zakłada, że mimo to możliwe jest prowadzenie badań nad grzecznością na poziomie mikro i makro. Zaproponowane przez nią podejście oparte na koncepcji ramy (frame-based analysis) pozwala na wzięcie pod uwagę nie tylko danej sytuacji z poziomu mikro, ale też historycznie i społecznie ukształtowanych zachowań językowych. Jeśli więc zastanawiamy się nad użyciem przez jednostkę konkretnej formuły językowej w danym kontekście, powinniśmy też wziąć pod uwagę to, jak zwykle ta formuła jest stosowana. Terkourafi (2005b) wiąże więc kontekst z normami społecznymi. Christie (2007, s. 285) zaś, w ramach teorii relewancji, traktuje kontekst jako psychologiczny konstrukt, gdzie czynniki zewnętrzne są częścią materii interakcji.

$\mathrm{W}$ badaniach opartych na paradygmacie postmodernistycznym materiał poddawany analizie stanowią dłuższe sekwencje zdań. Chodzi o to, by uchwycić kontekst, a nie tylko oderwaną od niego wypowiedź. W ten sposób można dostrzec, jak rozmówcy postrzegają dane wypowiedzi. To sprawia, że ocenianie danych przekazów nie jest już zadaniem badacza, ale samych rozmówców.

Badacze mają różne zdania w kwestii dokonywania uogólnień. Sara Mills (2011, s. 48-49) zakłada, że istnieje możliwość pewnej dozy generalizowania w obrębie tego typu badań, jest to jednak uogólnienie odnoszące się do tendencji, a nie do sztywnych praw. Podobne zdanie prezentuje Bousfield (2008, s. 38).

Poniższa tabela prezentuje w syntetyczny sposób zestawienie najważniejszych rozbieżności między podejściem do badań z wykorzystaniem założeń teorii klasycznych (przeddyskursywnych) i koncepcji opartych na nurcie dyskursywnym.

Tabela 2. Porównanie metodologii badań przeddyskursywnych i prowadzonych w nowym paradygmacie

\begin{tabular}{|c|c|}
\hline Przeddyskursywne badania grzeczności językowej & Badania prowadzone w paradygmacie dyskursywnym \\
\hline $\begin{array}{l}\text { 1. Analiza krótkich przykładów, często wymyślanych } \\
\text { przez badacza. }\end{array}$ & $\begin{array}{l}\text { 1. Analiza dłuższych fragmentów autentycznych } \\
\text { interakcji. }\end{array}$ \\
\hline $\begin{array}{l}\text { 2. Możliwość przewidzenia, jaki efekt na słuchaczu } \\
\text { wywrze dana wypowiedź. }\end{array}$ & 2. Interpretacja zależna od kontekstu. \\
\hline 3. Pojawienie się grzeczności jest intencją nadawcy. & $\begin{array}{l}\text { 3. Grzeczność jest dekodowana przez odbiorcę, to on } \\
\text { ją odczytuje. }\end{array}$ \\
\hline 4. Brak refleksji nad niegrzecznością. & $\begin{array}{l}\text { 4. Pojawienie się większej liczby badań nad nie- } \\
\text { grzecznością. }\end{array}$ \\
\hline $\begin{array}{l}\text { 5. Interpretacje zachowań grzecznościowych dokonywa- } \\
\text { ne przez badacza jako typowego użytkownika języka. }\end{array}$ & $\begin{array}{l}\text { 5. Interpretacje dokonywane przez uczestników inte- } \\
\text { rakcji; unikanie subiektywizmu. }\end{array}$ \\
\hline 6. System oparty na normach i nakazach. & 6. System wyłaniający się w procesie interakcji. \\
\hline 7. Dokonywanie daleko idących generalizacji. & $\begin{array}{l}\text { 7. Ostrożne podejście do generalizacji bądź zupełne } \\
\text { ich unikanie. }\end{array}$ \\
\hline
\end{tabular}

Źródło: opracowanie własne na podst. Politeness in East Asia (Kadar, Mills 2011, s. 7-8) 


\section{TRZECIA FALA}

Niektórzy lingwiści, jak na przykład Karen Grainger (2011, s. 167-188), uważają, że w tym momencie można już mówić o trzeciej fali badań nad grzecznością językową. Pierwszą reprezentują klasyczne teorie z koncepcją Brown i Levinsona na czele, drugą podejście postmodernistyczne i dyskursywne i wreszcie trzecią - socjologiczne i interakcyjne. Grainger (2011, s. 171) przedstawiła trzy głosy krytyczne wobec podejścia postmodernistycznego (dyskursywnego). Uznała, iż przyjęty tu model komunikacji oparty jest na kodowaniu i dekodowaniu znaczeń, podobnie jak miało to miejsce w teorii Brown i Levinsona. Poza tym uczestnicy interakcji dokonują post-factum ewaluacji swoich wypowiedzi; te dane stanowią esencję badania, przez co rola badacza znacznie się zmniejsza. Przytacza także zarzut wyartykułowany przez Terkourafi (2005a, s. 104) mówiący o tym, że podejście postmodernistyczne niebezpiecznie oddala badania nad grzecznością od lingwistyki, marginalizując znaczenie wyborów formuł językowych.

Jak to zwykle bywa, po przedstawieniu głosów krytycznych wobec określonych podejść proponowana jest koncepcja alternatywna. Zdaniem Grainger taką właśnie ma być podejście socjologiczne i interakcyjne. Nie jest ono zwykłym przeciwstawieniem się koncepcjom dyskursywnym czy klasycznym. Można nadal mówić tu o pozostawaniu w nurcie postmodernistycznym, szczególnie jeśli idzie o rozumienie i przyjęte znaczenie kontekstu. Materiał badawczy to wciąż niewymuszone konwersacje. Poszukuje się w nim sposobów tworzenia znaczeń przez uczestników interakcji. Zmiana optyki polega na tym, że proces komunikacji pojmuje się jako zdarzenie społeczne. Grzeczność jawi się jako element gry, co stanowi powrót do myśli Ervinga Goffmana (2008). Grainger do przedstawicieli nurtu socjologicznego zalicza siebie, ale też badaczy takich jak: Arundale (2010), Haugh (2011), O’Driscoll (2011) i Terkourafi (2005a).

\section{METODY BADAWCZE WYKORZYSTYWANE W BADANIACH NAD GRZECZNOŚCIĄ JĘZYKOWĄ}

Lingwiści badający grzeczność językową wciąż poszukują modelu badawczego. Można przyjąć, że część badaczy zakotwicza swoje analizy w teorii Brown i Levinsona i próbuje tę wielką koncepcję poprawić lub spojrzeć na nią z innej perspektywy. Inni zaś zupełnie odcinają się od dorobku poprzedników i wypracowują nowe rozwiązania. Na przyjęcie takiego czy innego modelu ogromny wpływ mają założenia badawcze i cel przedsięwzięcia. Pozostając w nurcie postmodernistycznym, badacze wybierają metody badawcze, które pozwalają na ekscerpcję materiału jak najbardziej autentycznego. By uzyskać takie dane, sięgają po nagrywanie niewymuszonych konwersacji, bądź notowanie zasłyszanych fragmentów 
rozmów. Niezbędne w takich przypadkach jest poinformowanie uczestników rozmowy o nagrywaniu konwersacji i uzyskanie ich zgody na to. Pojawia się więc wtedy pytanie, czy owo powiadomienie o rejestracji rozmowy nie wpłynie na zachowanie rozmówców?

Innym sposobem na zebranie materiału jest wykorzystanie zasobów telewizyjnych. Derek Bousfield (2008) analizował na przykład fragmenty wybrane z seriali dokumentalnych. Nasuwa się tu jednak pytanie o autentyczność takiego materiału. Ludzie występujący w telewizji mają świadomość tego, że są nagrywani. Do końca też nie możemy być pewni, czy cały program nie opiera się na scenariuszu, co mogłoby spowodować postawienie zarzutu o nieautentyczność danych.

Badacze, którzy pozostają pod wpływem teorii Brown i Levinsona, często korzystają z metod badawczych stosowanych w pragmatyce, jak chociażby $D i$ scourse Completion Test (DCT). DCT to test polegający na uzupełnieniu fragmentów dyskursu. Składa się z kilku zadań - nakreślona jest sytuacja, opisany kontekst, a badany proszony jest jedynie o udzielenie odpowiedzi bądź o reakcję językową, jaka mu się nasuwa po zapoznaniu się z zadaniem (pytaniem). Ta technika badawcza pozwala na wprowadzenie kontekstu, co zbliża ją do nurtu postmodernistycznego, ale jednocześnie często wykorzystywana jest do badań nad aktami mowy, co z kolei wiąże ją z teorią klasyczną.

W czasie mojego pobytu w Stanach Zjednoczonych, który był możliwy dzięki stypendium Fundacji Kościuszkowskiej, wzięłam udział w konferencji 19th International Conference on Pragmatics and Language Learning (19. Międzynarodowa Konferencja Pragmatyki i Uczenia się Języków Obcych ${ }^{9}$ ), która odbyła się w dniach 24-26 kwietnia 2014 roku. Wiele wystąpień lingwistów z całego świata dotyczyło właśnie zagadnień grzeczności językowej ujmowanej w perspektywie nauczania języków obcych ${ }^{10}$. Mnie szczególnie zainteresowały metody badawcze, jakie wykorzystuje się w najnowszych badaniach pragmalingwistycznych.

${ }^{8}$ W 2012 roku otrzymałam stypendium Fundacji Kościuszkowskiej na prowadzenie badań oraz nauczanie języka polskiego w Uniwersytecie Indiana, w ośrodku Bloomington. Pracowałam tam w latach 2012-2014.

${ }^{9}$ Tłumaczenia z języka angielskiego - własne.

${ }^{10}$ Por. tytuły wystąpień: Developing L2 pragmatics in Mandarin: Acceptances of invitations and offers (Rozwój pragmatyczny w języku chińskim jako drugim: Akceptacja zaproszeń i propozycji); Apologies produced by Mexican learners of English (Akty przepraszania w języku Meksykanów uczacych się języka angielskiego); Teaching how to apologize (Nauczanie przepraszania); "Well...I'm not that good" - Responding to a compliment in Spanish and English L1 and L2 (,, Tak naprawdę nie jestem taki dobry" - Reakcje na komplementy w języku hiszpańskim i angielskim); Russian and Spanish apologies: A contrastive pragmalinguistic and sociopragmatic study (Rosyjskie $i$ hiszpańskie przeprosiny: kontrastywne studium pragmalingwistyczne $i$ socjopragmatyczne); Teaching compliments and compliment responses to intermediate-level learners of Spanish in the foreign language classroom (Nauczanie komplementowania i reakcji na komplementy $w$ grupach średnio zaawansowanych osób uczacych się języka hiszpańskiego). Pełny program konferencji jest dostępny na stronie internetowej: http://www.indiana.edu/ pll/program/schedule-final.pdf [21.06.2017]. 
Poszukiwanie i analiza aktów mowy skłoniła wielu badaczy do wykorzystywania testu DCT, czyli Discourse Completion Test. Cesar Felix-Brasdefer w wystąpieniu Pragmatic Developement in Short-term Study Abroad: Refusing, Mitigating, and Individual Variation (Rozwój pragmatyczny podczas krótkich kursów językowych za granica: Odmawianie, tagodzenie i inne rozwiąania) przedstawił metodologię badań, które przeprowadził w trzech grupach. Pierwszą byli studenci amerykańscy, którzy uczyli się języka hiszpańskiego w USA i wyjechali na ośmiotygodniowy kurs językowy do Meksyku, drugą studenci, którzy uczyli się tylko w USA, zaś trzecią, porównawczą grupę, stanowili studenci meksykańscy, tzw. rodzimi użytkownicy języka. Modyfikacja testu polegała na tym, że Felix-Brasdefer przeprowadzał go ze studentami ustnie, bez konieczności wypełniania przez nich formularza, reakcje językowe były więc rejestrowane w formie nagrania. Dodatkowo, oprócz opisania kontekstu w kwestionariuszu, stosował bodźce wizualne i dźwiękowe, by nakreślić i lepiej zobrazować sytuację.

Inną techniką badawczą, zbliżoną do testu DTC, jest tzw. role-play ${ }^{11}$, czyli odgrywanie ról, scenek na zadany temat. Zasadnicza różnica polega na tym, że w teście DTC nakreśla się w formie pisemnej sytuację i rejestruje się językową reakcję jednej osoby, w przypadku metody role-play (odgrywania ról) potrzeba co najmniej dwojga uczestników badania, którzy wykonują, opisane im wcześniej, zadanie językowe. Rachel L. Shively w swoim wystąpieniu na temat rozwoju umiejętności pragmatycznych w przypadku osób uczących się języka obcego podczas uczestnictwa $\mathrm{w}$ wymianach studenckich, zaproponowała następujące postępowanie badacze: studenci wcielali się w różne role i korespondowali ze sobą drogą mejlową. Następnie badaczka analizowała sposoby konstruowania próśb, odmów, zwrotów grzecznościowych itp. Zarzut, jaki pojawił się w przypadku tej procedury, odnosił się do kwestii autentyczności. Uczestnicy badania mogli odgrywać role studentów, ale też profesora. $Z$ doświadczeń innych badaczy zgromadzonych na sali obrad podczas konferencji wynikało, że jeśli uczestnicy badania nie odgrywają w scenkach ,samych siebie”, są znacznie bardziej skłonni do prezentowania postaw skrajnych i nie przedstawiają autentycznych zachowań językowych. By urozmaicić i dopełnić tę technikę badawczą, postulowano także, żeby po zakończeniu scenek uczestnicy mogli wymienić swoje opinie i refleksje na temat tego, jak się czuli w trakcie badania, czy mogli w pełni „wyrazić siebie” w języku, którego się uczyli.

Jeszcze inną metodę zaproponował Daniel Dewey w wystąpieniu Documenting Pragmatic Exchanges during Study Abroad through Journal Entries, Questionnaires, Interviews, and Participant Observation (Dokumentowanie wymian pragmatycznych $w$ trakcie studiów za granica poprzez pisanie dzienników, kwestionariusze, wywiady i obserwację uczestniczaca). Poprosił on grupę studentów, którzy od dwóch tygodni przebywali za granicą w ramach wymiany studenckiej,

${ }^{11} \mathrm{~W}$ cytowanej literaturze znalazłam trzy sposoby zapisu tego terminu: role-play, role play i roleplay. W tej pracy będę konsekwentnie posługiwać się pierwszym zapisem. 
o spisanie swoich doświadczeń w zakresie posługiwania się językiem obcym. Analiza tych esejów skłoniła badacza do wyciągnięcia następujących wniosków: studenci skupiali się na przedstawieniu problemów z zakresu słownictwa i gramatyki, nie zdawali sobie sprawy z zakłóceń w obszarze kompetencji pragmatycznej; jeśli pojawiały się jakieś refleksje na ten temat, najczęściej dotyczyły one sposobów formułowania próśb, „grzecznego" kłócenia się i radzenia sobie w kontakcie z obsługą klienta i usługodawcami.

Ciekawe zestawienie metod badawczych wykorzystywanych w badaniach nad grzecznością językową pojawia się także w książce The Handbook of Intercultural Discourse and Communcation (2012). Janet Holmes, autorka części poświęconej grzeczności w dyskursie interkulturowym, wylicza następujące techniki badawcze: kwestionariusze, wywiady, role-plays, czyli scenki, obserwację uczestniczącą oraz nagrywanie autentycznych rozmów (Holmes 2012, s. 212-213). Badania kwestionariuszowe to oczywiście testy DCT ${ }^{12}$. Holmes przyznaje, że jest to najczęściej stosowana technika badawcza. Sprawdza się przede wszystkim przy analizowaniu tego, jak poszczególne akty mowy są realizowane przez użytkowników różnych języków. Do zalet testów DCT autorka zalicza możliwość pozyskania obszernego materiału od dużej grupy badawczej w stosunkowo krótkim czasie oraz łatwość kontrolowania i manipulowania zmiennymi, takimi jak: rola, status i dystans społeczny. Największą wadą, zdaniem Holmes, jest zaś to, że uczestnicy tak zaprojektowanych badań nie mają możliwości negocjowania znaczeń, odpowiadają zwykle jednym zdaniem, co w rzeczywistej rozmowie rzadko się zdarza. Holmes twierdzi, że testy DCT dostarczają informacji o stereotypowym obrazie aktów mowy, a nie o ich rzeczywistym użyciu ${ }^{13}$. Inna, wymieniona przez tę lingwistkę metoda, czyli odgrywanie ról, jest bliższa rzeczywistym zachowaniom językowym. Występują tu dłuższe dialogi, a niektórzy badacze (np. Felix-Brasdefer 2008 za: Holmes 2012 s. 214) zachęcają uczestników badania do krótkich ocen swoich wypowiedzi, zaraz po odegranej scence.

Kolejna technika opisana przez Holmes to pozyskiwanie danych autentycznych, czyli nagrywanie realnych rozmów. Materiał badawczy można nagrywać na urządzeniach audio, wtedy mamy tylko zapis dźwiękowy lub na kamerze, a w takim przypadku analizować można również sferę pozawerbalną ${ }^{14}$. Dodatkowo, nagrywanie sytuacji z życia codziennego pozwala, zdaniem Holmes, dokonywać ewaluacji danych; uczestnikom badania można odtworzyć scenki z ich udziałem i poprosić ich o analizę zachowań. Oprócz krótkotrwałych, jednorazowych ba-

${ }^{12}$ Holmes podaje obszerną listę badań z wykorzystaniem testów DCT. Lingwiści skupiali się na przedstawieniu różnic w realizacji aktów mowy w różnych językach (Holmes 2012, s. 215).

${ }^{13}$, ,...) DCTs provide information on stereotypical shape of the speech act" (Beebe and Cummings 1996, s. 80-81), rather than on actual usage" (Holmes 2012, s. 213).

${ }^{14}$ Holmes przywołuje między innymi pracę pod redakcją Leo Hickey'a i Mirandy Stewart (2005), w której przedstawiono strategie grzecznościowe używane w dwudziestu dwóch społeczeństwach europejskich (Holmes 2012, s. 215). 
dań, znaleźć można też przykłady badań wieloetapowych, prowadzonych w dłuższym przedziale czasowym. Anne Barron (2003) postawiła sobie za cel zbadanie rozwoju kompetencji pragmalingwistycznej u trzydziestu trzech Irlandczyków uczących się języka niemieckiego. Badania zostały przeprowadzone podczas ich pobytu na wymianie zagranicznej w Niemczech i trwały rok. Językoznawczyni zastosowała szereg technik badawczych, czyli triangulację - metodę zapewniającą wyższą jakość prowadzonych badań przez dobór różnych, uzupełniających się technik. Jak w większości badań pragmalingwistycznych, skupiła się na analizie aktów mowy. Przeprowadziła badania kwestionariuszowe przed powrotem i po powrocie studentów z zagranicy, testy DCT dotyczące realizacji próśb, testy FDCT sprawdzające użycie aktów oferowania i odmawiania, odgrywanie scenek i wywiady je analizujące oraz ocenę własnych osiągnięć. Innowacją, w stosunku do wcześniej opisanych przeze mnie technik, jest kwestionariusz FDCT - free discourse completion task ${ }^{15}$ (Barron 2003, s. 83) Jest to autorska metoda wypracowana przez Anne Barron. W odróżnieniu od tradycyjnego testu DCT, badaczka, po nakreśleniu w kwestionariuszu sytuacji, prosi respondentów o napisanie dialogu, czyli jednoczesne występowanie w dwóch rolach w konwersacji. W drugiej części kwestionariusza proponuje zaś zadanie polegające na dopisaniu brakującego fragmentu rozmowy, oczywiście dotyczy to zdania wprowadzającego akt mowy proponowania.

Podsumowując, przytoczone wyżej przykłady badań wyraźnie wskazują na to, że:

- analizy językowych zachowań grzecznościowych wciąż pozostają pod wpływem klasycznych teorii grzeczności językowej i aktów mowy,

- nurt pragmalingwistyczny jest niezwykle silny; jego niewątpliwą zaletą jest to, że badania prowadzone w tym obszarze pozwalają uzyskać dane w postaci policzalnej, obiektywnej.

\subsection{PODEJŚCIA DO BADAŃ NAD GRZECZNOŚCIĄ JĘZYKOWĄ W GLOTTODYDAKTYCE POLONISTYCZNEJ}

Badania nad grzecznością językową prowadzone są również w obrębie glottodydaktyki polonistycznej. Praktykujący glottopoloniści na co dzień stykają się z problemami uczących się w zakresie posługiwania się zasadami etykiety. To daje impuls do bliższego przyjrzenia się jej regułom. Poza tym także autorzy ESOKJ (2003) wskazują na istotność kompetencji socjolingwistycznej, a co za tym idzie, także samej grzeczności w nauczaniu języków obcych.

${ }^{15}$ Test polegający na swobodnym wypełnianiu luk. 
Na gruncie glottodydaktyki polonistycznej powstało wiele prac koncentrujących się wokół grzeczności językowej. Wśród nich bardzo ważne miejsce zajmują dwie monografie - są to prace S. Schmidt (2004) i A. Żurek (2008a). Sybille Schmidt rozpoczęła swoje badania od analizy podręczników. Uwzględniła 35 publikacji z lat 1962-2001, z których część była przeznaczona dla osób niemieckojęzycznych, a inne dla bliżej nieokreślonego kręgu odbiorców. Następnie przeszła do zasadniczej części badania, czyli wywiadów indywidualnych. Badaczka nakreśliła informatorom 147 sytuacji komunikacyjnych i odnotowała ich językowe reakcje. W badaniu uczestniczyło pięćdziesiąt osób. S. Schmidt oparła swoje założenia na klasycznym modelu grzeczności.

Anna Żurek postawiła sobie zaś za cel ,zdiagnozowanie faktycznego stanu procesu uczenia się aktów grzeczności językowej u obcokrajowców" (Żurek 2008a, s. 57). Wykorzystała technikę testu diagnostycznego, bardzo zbliżoną $\mathrm{w}$ formie do tego, co w literaturze angielskiej określa się jako DCT. Poprosiła respondentów o zapisanie językowych reakcji na przedstawione $\mathrm{w}$ formie pisemnej krótkie scenki sytuacyjne. Kolejne zadania wymagały od cudzoziemców użycia zwrotów grzecznościowych. Po zgromadzeniu materiału badaczka dokonała analizy błędów popełnianych przez osoby uczące się języka polskiego jako obcego.

Analiza zaprezentowana w obu omówionych wyżej monografiach skupiała się na śledzeniu błędów w zakresie posługiwania się przez cudzoziemców etykietą polską. Podobne podejście znaleźć można także w kilku artykułach. Reprezentują je prace A. Żurek (2008b), A. Czechowskiej (2005), A. Krawczuk (2008), B. Janowskiej-Wierzchoń (2005). Jakie korzyści płyną z takiego podejścia? Przede wszystkim jest to sposób na ujawnienie miejsc trudnych, czyli tych aktów grzeczności (przywołane powyżej prace właśnie akt grzecznościowy uznają za jednostkę analizy), które sprawiają cudzoziemcom najwięcej trudności. Poza tym można się także w ten sposób przyjrzeć, jak braki w zakresie kompetencji językowej wpływają na funkcję illokucyjną aktów grzecznościowych.

Inne podejście do badań nad grzecznością językową prezentują autorzy, którzy zdecydowali się na przeanalizowanie materiałów glottodydaktycznych, głównie podręczników do nauczania języka polskiego jako obcego. Przywołać można tu artykuły M. M. Nowakowskiej (2011), E. Szkudlarek-Śmiechowicz (2008), E. Sztabnickiej (2011), S. Taboła (2010, 2012), M. Gaszyńskiej-Magiery (2005). Analizy polegały zwykle na ekscerpcji zwrotów grzecznościowych z materiałów i komentowaniu ich funkcji, zastosowań, bądź konfrontowaniu z językiem nauczanej grupy cudzoziemców. Większość autorów zdecydowała się na sprowadzenie jednostki badania do aktu mowy. Analizowano więc podziękowania, powitania i życzenia, ale też etykietalną obudowę tych i innych aktów w postaci zwrotów adresatywnych. Pewną innowacyjność w tym obszarze wprowadziła Małgorzata Gaszyńska-Magiera. Metodologia jej badań nie opiera się na jednostce, jaką zwy- 
kle był akt mowy, ale na elemencie, który został przez nią określony jako „zasada rządząca polską grzecznością językową". Dlatego też jej dociekania zbliżone są do analizy dyskursu, w którym poszukuje się strategii konwersacyjnych.

Kolejną kategorię stanowią prace, których głównym celem było ujęcie komparatystyczne. Wyróżnić tu można artykuły M. M. Nowakowskiej (2008), A. Rabczuk (2012) i A. Stryjeckiej (2011). Nadrzędnym celem jest tu porównanie lingwakultury języka polskiego i innego bądź też innych języków. Badaczki wykorzystały doświadczenie zdobyte podczas pracy lektora lub analizowały wypowiedzi obcokrajowców. Język polski konfrontowano w tych pracach z językiem ukraińskim, słowackim, słoweńskim, niemieckim i włoskim. Wskazywano na różnice i „miejsca trudne” w nauczaniu grzeczności językowej. Badania prowadzono także w grupach międzynarodowych.

Niezwykle cennym elementem wymienionych wyżej prac jest zwrócenie uwagi na interferencje międzyjęzykowe, które utrudniają cudzoziemcom poprawne opanowanie polskiej etykiety językowej. Transfer negatywny został zauważony przez Marię Nowakowską, Ałłę Krawczuk, Agnieszkę Stryjecką i Annę Rabczuk. Ciekawie zostało także zaprezentowane porównywanie lingwakultur. Zwykle takiego zadania podejmują się glottodydaktycy, którzy doskonale poznali język drugi i w tym środowisku językowym nauczają języka polskiego. Ich doświadczenie ma dużą wartość i w przyszłości może być pomocne podczas pisania podręczników przeznaczonych dla poszczególnych grup narodowościowych.

Najnowsze prace dotyczące problemu grzeczności językowej w nauczaniu języka polskiego jako obcego wyróżnia nowatorskie podejście do badań. Przykładem wykorzystania nowej metodologii jest artykuł A. Rabczuk (2015). Ta praca prezentuje odmienne od pozostałych spojrzenie na grzeczność językową ${ }^{16}$. Autorka wykorzystała ankietę hybrydową, dzięki której zebrała opinie cudzoziemców na temat ich zmagań z polską grzecznością językową. Kwestionariusz ankiety hybrydowej charakteryzuje się tym, że zawiera pytania zamknięte, dające odpowiedzi, które można przedstawić w formie ilościowej, a także pytania otwarte, które należy analizować korzystając z podejścia jakościowego.

$\mathrm{Z}$ jeszcze innej metody zdecydowała się skorzystać autorka niniejszego tekstu, przygotowując w latach 2014-2017 swoją rozprawę doktorską ${ }^{17}$. Badaczka chciała, by model polskiej grzeczności językowej został oceniony przez cudzoziemców. Zaprojektowała więc badanie, w którym główną techniką był wywiad swobodny, metoda znana w naukach społecznych. Dzięki temu zebrała szereg wypowiedzi dających obraz polskiej grzeczności językowej w oczach cudzoziemców uczących się języka polskiego. Pozwoliło to na przyjrzenie się temu ciekawemu elementowi kultury polskiej z zupełnie nowej perspektywy.

${ }^{16}$ Obszerne omówienie wszystkich wymienionych prac znajduje się w pracy doktorskiej Emilii Sztabnickiej-Gradowskiej. Tekst jest dostępny w repozytorium cyfrowym UŁ.

${ }^{17}$ Tekst jest dostępny w repozytorium cyfrowym UŁ. 
Autorki dwóch wyżej wymienionych prac skupiły się na pozyskaniu opinii osób uczących się języka polskiego. W tym właśnie miejscu widać zmianę perspektywy. Wybrane techniki badawcze są zgodne z założeniami teorii postmodernistycznych. Można powiedzieć, że te prace przedstawiają socjologiczne spojrzenie na polską etykietę. Dzięki nim ujawniono szereg opinii o polskiej grzeczności. Cudzoziemcy postrzegają więc polszczyznę jako język obfitujący w różnorodne formy honoryfikatywne, akcentują trudności w określeniu dystansu między rozmówcami i problemy z komunikacją (szczególnie z osobami starszymi), braki w zakresie stosowania zasad grzeczności językowej w kontaktach w sklepach, na dworcach, na poczcie i w środowisku akademickim oraz w przypadku posługiwania się formami pisemnymi.

Powyższe zestawienie i krótka charakterystyka wybranych prac pokazuje, że większość glottopolonistów oparło swoje badania nad grzecznością językową na modelu klasycznym. Klasyfikacja aktów grzeczności językowej Małgorzaty Marcjanik $(1997,2008)$ jest niezwykle użyteczna. Pozwala na precyzyjne zebranie materiału badawczego i przeprowadzenie analizy ilościowej, jak i jakościowej. Najnowsze prace pokazują jednak także, że możliwe jest wykorzystanie podejścia postmodernistycznego. Dzięki temu glottodydaktycy otrzymują obraz problemów związanych z grzecznością z różnych perspektyw.

\section{PODSUMOWANIE}

Ucząc cudzoziemców grzeczności językowej, powinniśmy o tym procesie myśleć nie tylko z pozycji systemów komunikowania się, ale przede wszystkim z perspektywy poznawania innych kultur i rzeczywistości społecznych. Postmodernistyczne teorie grzeczności językowej dają badaczom możliwość na przyjrzenie się temu elementowi z nowej perspektywy.

Wszystkie przedstawione wyżej artykuły są doskonałym przykładem przełożenia osiągnięć językoznawstwa polskiego na potrzeby glottodydaktyki polonistycznej. Badania nad grzecznością językową Polaków mogą być niezwykłą inspiracją dla autorów podręczników do nauczania języka polskiego jako obcego, czy samych nauczycieli. Dzięki podbudowie empirycznej będziemy mogli uczyć cudzoziemców języka, którym na co dzień mówią Polacy. 


\section{BIBLIOGRAFIA}

Arundale, R., 2010, Constituting Face in Conversation: Face, facework, and Interactional Achievement, ,Journal of Pragmatics”, nr 42(8), s. 2078-2105.

Austin J. L., 1962, How to do things with words, Harvard University Press.

Austin J. L., 1993, Jak działać słowami, w: Austin J. L., Mówienie i poznawanie, Warszawa.

Barron A., 2003, Acquisition in Interlanguage Pragmatics. Learning how to do things with words in study abroad context, Filadelfia, s. 79-154.

Beebe L., Cummings M., 1996, Natural speech act data versus written questionnaires data: How data collection method affects speech act performance, w: S. Gass, J. Neu (red.), Speech Acts across Cultures: Challenges to Communication in a Second Language, Berlin, s. 65-86.

Bourdieu P., 1991, Language and Symbolic Power, Polity Press, Cambridge.

Bousfield D., 2008, Impoliteness in Interaction, Amsterdam-Filadelfia.

Brown P., Levinson S., 1978, Universals in language usage: Politeness phenomena, w: E. N. Goody (red.), Questions and politeness: strategies in social interaction, Cambridge, s. 56-311.

Brown P., Levinson S., 1987, Politeness. Some universals in language usage, Cambridge.

Byczkowska D., 2012, Habitus, w: Stownik socjologii jakościowej, K. T. Konecki, P. Chomczyński (red.), Warszawa, s. 102-103.

Christie C., 2007, Relevance theory and politeness, „Journal of Politeness Research”, t. 3, s. 269-294.

Culpeper J., 2005, Impoliteness and entertainment in the television quiz show: The weakest link, „Journal of Politeness Research”, t. 1, s. 35-72.

Czechowska A., 2005, O poprawności gramatycznej aktów grzecznościowych u cudzoziemców, w: P. Garncarek (red.), Nauczanie języka polskiego jako obcego i polskiej kultury w nowej rzeczywistości europejskiej: materiaty z VI Międzynarodowej Konferencji Glottodydaktycznej, Warszawa, s. 104-114.

Eelen G., 2001, A Critique of Politeness Theories, Manchester.

Félix-Brasdefer J., 2008, Politeness in Mexico and the United States: A Contrastive Study of the Realization and Perception of Refusals, Amsterdam.

Foucault M., 1977, Archeologia wiedzy, Warszawa.

Gaszyńska-Magiera M., 2005, Nauczanie komunikacji w podręcznikach do nauki JPJO w kontekście polskiej etykiety językowej, w: P. Garncarek (red.), Nauczanie języka polskiego jako obcego i polskiej kultury w nowej rzeczywistości europejskiej, Warszawa, s. 115-120.

Geyer N., 2008, Discourse and politeness: Ambivalent Face in Japanese, Londyn, s. 1-56.

Goffman E., 1967, Interaction ritual: essays on face-to-face behavior, Chicago.

Goffman E., 2006, Rytuat interkacyjny, Warszawa, s. 5-46.

Grainger K., 2011, 'First order' and 'second order' politeness: Institutional and intercultural contexts, w: Linquistic Politeness Research Group (red.), Discursive Approaches to Politeness, Berlin-Boston, s. 167-188.

Grice P., 1977, Logika i konwersacja, „Przegląd Humanistyczny”, z. 6, s. 85-99.

Haugh M., 2011, Humour, Face and Im/politeness in Getting Acquainted, w: B. Davis, M. Haugh, A. J. Merrison (red.), Situated Politeness, Londyn-Nowy Jork, s. 165-186.

Hickey L., Stewart M. (red.), 2005, Politeness in Europe, Clevedon.

Holmes J., 2012, Politeness in Intercultural Discourse and Communication, w: The Handbook of Intercultural Discourse and Communcation, Hobocken, s. 205-228.

Ide S., 1989, Formal forms and discernment: two neglected aspects of universals of linguistic politeness, „Multilinqua”, t. 8, nr 2-3, s. 223-248.

Janowska-Wierzchoń B., 2005, Grzeczność rzeczywista i pozorna w sposobach zwracania się do innych. Między gramatyka a pragmatyka, w: P. Garncarek (red.), Nauczanie języka polskiego jako obcego i polskiej kultury w nowej rzeczywistości europejskiej, Warszawa, s. 121-126. 
Kadar D. Z., Mills S., 2011, Politeness in East Asia, Cambridge University Press, Cambridge.

Krawczuk A., 2008, Nauczanie Ukraińców polskiej etykiety językowej (zwracanie się do adresata), w: W. Miodunka, A. Seretny (red.), W poszukiwaniu nowych rozwiazań. Dydaktyka języka polskiego jako obcego u progu XXI wieku, Kraków, s. 301-312.

Lakoff R., 1973, The logic of politeness; or, minding your P's and Q's, w: Papers from the Ninth Regional Meeting of the Chicago Linguistics Society, Chicago, s. 292-305.

Lakoff R., Ide S. (red.), 2005, Broadening the Horizon of Linguistic Politeness, Amsterdam-Filadelfia. Leech G., 1983, Principles of pragmatics, Londyn-Nowy Jork.

Locher, M., 2006, Polite behavior within relational work: the discursive approach to politeness, „Multilingua”, s. 249-267.

Locher M., Watts R., 2005, Politeness theory and relational work, „Journal of politeness research”, s. $9-33$.

Marcjanik M., 1997, Polska grzeczność językowa, Kielce.

Marcjanik M., 2008, Grzeczność w komunikacji językowej, Warszawa.

Mills S., 2003, Gender and Politeness, Cambridge.

Mills S., 2011, Discursive approaches to politeness and impoliteness, w: Linquistic Politeness Research Group (red.), Discursive Approaches to Politeness, Berlin-Boston, s. 19-56.

Nowakowska M. M., 2008, Językowy savoir-vivre: nauczanie polskich form grzecznościowych na gruncie stowackim, w: W. Miodunka, A. Seretny (red.), W poszukiwaniu nowych rozwiazań. Dydaktyka języka polskiego jako obcego u progu XXI wieku, Kraków s. 323-328.

Nowakowska M. M., 2011, Podstawy etykiety językowej w wybranych podręcznikach do nauki języka polskiego jako obcego, „Acta Universitas Lodziensis. Kształcenie Polonistyczne Cudzoziemców", t. 18, B. Grochala, M. Wojenka-Karasek (red.), s. 201-210.

O'Driscoll J., 2011, Some issues with the concept of face: when, what, how and how much?, w: F. Bargiela-Chiappini, D. Kádár (red.), Politeness Across Cultures, Londyn, s. 17-41.

Rabczuk A., 2012, „Elo ziom!”, a może „Dzień dobry Panu”? - grzeczność w procesie glottodydaktycznym, w: P. Garncarek, P. Kajak (red.), Kultura popularna w nauczaniu języka polskiego jako obcego. Materiaty z konferencji naukowej, Warszawa, s. 235-249.

Rabczuk A., 2015, „Jak całować polskim kobietom ręce?” Analiza i interpretacja wyników badań na temat polskiej grzeczności językowej cudzoziemców, w: I. Bundza, J. Kowalewski, A. Krawczuk, A. Śliwiński (red.), Język polski i polonistyka w Europie Wschodniej: przeszłość i współczesność, Kijów 2015, s. 499-514.

Schmidt S., 2004, Kompetencja komunikacyjna Niemców w polskich aktach grzeczności językowej. Perspektywa glottodydaktyczna, Pułtusk.

Searle J., 1969, Speech Acts, Cambridge.

Searle J., 1987, Czynności mowy, Warszawa.

Sifianou M., 2010, Linguistic politeness: Laying the foundations, w: Interpersonal pragmatics, Berlin-Nowy Jork, s. 17-42.

Song S., 2012, Politeness and Culture in Second Language Aquisition, Basin.

Stryjecka A., 2011, Wszystkiego najlepszego i połamania czego?, „Acta Universitatis Lodziensis. Kształcenie Polonistyczne Cudzoziemców”, t. 18, B. Grochala, M. Wojenka-Karasek (red.), s. $217-222$.

Szkudlarek-Śmiechowicz E., 2008, Grzecznościowe akty mowy w nauczaniu języka polskiego jako obcego na poziomie elementarnym (A1), „Acta Universitatis Lodziensis. Kształcenie Polonistyczne Cudzoziemców”, t. 16, G. Zarzycka, G. Rudziński (red.), s. 119-125.

Sztabnicka E., 2011, Wzory grzecznościowe w podręczniku do nauki języka polskiego jako obcego Hurra!!! Po polsku 1, „Acta Universitatis Lodziensis. Kształcenie Polonistyczne Cudzoziemców”, t. 18, B. Grochala, M. Wojenka-Karasek (red.), s. 211-216.

Taboł S., 2010, Etykieta językowa zawarta w podręcznikach do nauki języka polskiego jako obcego, „Języki Obce w Szkole”, nr 3, Warszawa, s. 22-33.

Taboł S., 2012, Aspekt socjokulturowo-lingwistyczny w glottodydaktyce języka polskiego, Racibórz. 
Terkourafi M., 2005a, Beyond the micro-level in politeness research, „Journal of Politeness Research", nr. 1(2), s. 237-263.

Terkourafi M., 2005b, An argument for a frame-based approach to politeness: evidence from the use of the imperative in Cypriot Greek, w: R. Lakoff, S. Ide (red.), Broadening the Horizon of Linguistic Politeness, Amsterdam-Filadelfia, s. 99-117.

Terkourafi M., 2007, Toward a unified theory of politeness, impoliteness and rudeness, w: D. Bousfield, M. Locher (red.), Impoliteness in Language, Berlin-Nowy Jork, s. 45-74.

The Handbook of Intercultural Discourse and Communcation, 2012, Hobocken.

Watts R., 2003, Politeness, Nowy Jork.

Watts R. J., Ide S., Ehlich K., 1992, Politeness in Language, Berlin-Nowy Jork.

Wenger E., 1998, Communities of Practice: Learning, Meaning, and Identity, Cambridge.

Żurek A., 2008a, Grzeczność językowa w polszczyźnie cudzoziemców. Wybrane zagadnienia, Łask.

Żurek A., 2008b, Tworzenie aktów grzecznościowych przez cudzoziemców uczacych się języka polskiego jako obcego, w: W. Miodunka, A. Seretny (red.), W poszukiwaniu nowych rozwiazań. Dydaktyka języka polskiego jako obcego u progu XXI wieku, Kraków, s. 313-322.

Emilia Sztabnicka-Gradowska

\section{CONTEMPORARY LINGUISTIC POLITENESS THEORIES AND THEIR INFLUENCE ON RESEARCH IN POLISH LANGUAGE GLOTTODIDACTICS AREA}

Keywords: linguistic politeness, Polish language glottodidactics, research on linguistics politeness

Abstract. The main aim of this paper is to present the various approaches to politeness research which have been documented by researchers from all over the word in last fifty years. In the first part of the article the author compares the most well-known and influential theories of politeness. Then the critique of these approaches is presented in details. In the next step the author examines new theories that arise after the discussion. These approaches are called postmodern and discursive. Part three of the paper focus on the concepts that presents different idea than postmodern or discursive paradigm. In the last part the author gives examples of the newest approaches to the research that studied linguistic politeness and also presents the impact these may have on Polish language glottodidactics. 